\title{
Notiesāto amatpersonu skaita dinamika pretkorupcijas kontekstā
}

\author{
Dr. iur. Anatolijs Kriviṇš \\ Daugavpils Universitāte, Izglìtības un vadības fakultāte, \\ Pedagoǵijas un pedagoǵiskās psihologijas katedra, Latvija \\ anatolijs777@gmail.com
}

\section{Kopsavilkums}

Raksts ir veltìts būtiskas problēmas izzināšanai - pret korupciju vērsto darbību efektivitātes korelācijai ar notiesāto amatpersonu skaitu. Publikācijā atspoguḷots pētỉjums, vai par korupciju notiesāto valsts amatpersonu skaita pieaugums / samazinājums liecina par efektīvāku cīṇu pret korupciju. Pētījuma rezultāti liecina, ka nepastāv zinātniski pierādīta korelācija starp amatpersonu skaitu, kas notiesātas par korupciju, un valstī realizēto pret korupciju vērsto darbību efektivitāti.

Atslēgvārdi: cīna pret korupciju, notiesāto amatpersonu skaits.

Vērtējot pretkorupcijas pasākumu iedarbīgumu, viens no diskutablākajiem ir jautājums, kuri rādītāji ḷauj secināt, ka valsts pretdarbība korupcijai ir efektīva. Šajā kontekstā publiskajā telpā bieži tiek uzsvērts notiesāto amatpersonu skaita pieaugums vai samazinājums.

Pretkorupcijas kontekstā notiesāto amatpersonu skaita dinamikai pievērš uzmanību gan ārvalstu, gan arī Latvijas zinātnieki. Piemēram, korupcijas pētnieks V. Nomokonovs norāda, ka diezgan nelielais tiesā izskatīto korupcijas lietu skaits vedina domāt, ka korupcijas sērga ir apsēdusi arī noziedzības apkarošanas iestādes. Turpretī liels korupcijas lietu skaits tiesās parasti liecina par to, ka valstī notiek aktīva cīṇa ar korupciju [16, 124].

Politolog̀e R. Kārkliṇa grāmatā "Korupcija postkomunisma valstīs" uzsver:

"Naivs novērotājs var domāt - ja ierosinātas tikai dažas lietas, tas nozīmē, kā korupcijas līmenis ir zems. Patiesībā, visticamāk, ir gluži pretēji: apsūdzību mazais skaits var liecināt par ḷoti augstu korupcijas līmeni, kā arī par to, ka tā ir pārṇēmusi arī tiesu sistēmu." $[6,46]$ 
2015. gada decembrī korupcijas pētnieks V. Kalniņš, komentējot Latvijas tiesu datus par 2014. gadu, pauž šādu viedokli:

"Mazais notiesāto amatpersonu skaits atklāj satraucošu tendenci, kas liecina par cīnas pret korupciju vājināšanos. Daudz aktīiāka cīna ar amatpersonu korupciju bija 2005. gadā, kad notiesātas tika 96 amatpersonas." [21]

Šeit pieminētie apgalvojumi pirmšķietami (prima facie) ir log̣iski, tomēr, lai risinātu minēto problēmu teorētiski, ir jāpievērš uzmanība arī turpmāk izklāstītajiem apsvērumiem.

Pirmkārt, jāṇem vērā, ka cīṇai pret korupciju (rakstā ar korupciju jāsaprot uzticētā publiskā resursa l̦aunprātīga izmantošana privātās interesēs) ir duāls raksturs.

Korupcijas ierobežošanā neapšaubāmi svarīgi ir elementi, kas kopsakarā veido korupcijas apkarošanas apjomu:

- kriminālatbildības noteikšana par amatpersonas pretlikumīgiem nodarījumiem sava vai citu personu labuma gūšanai, šādu nodarijjumu izmeklēšana un operatīvā darbība, vainīgo personu saukšana pie likumā paredzētās atbildības (ieskaitot taisnīgu un àtru tiesas procesu), sodu noteikšana un piemērošana (spēkā stājies tiesas spriedums), ar kriminālatbildību saistīto specifisko jautājumu risināšana;

- starptautiskā sadarbība (ieskaitot izdošanu, notiesāto personu nodošanu, savstarpēju tiesisko palīdzību; kriminālās tiesvedības tālāknodošanu, sadarbību tiesībaizsardzības jomā, kopīgu izmeklēšanu);

- noziedzīgi iegūtu līdzekḷu atgūšana, kā arī tehniska palīdzība un informācijas apmaina.

Jāuzsver, ka pretdarbība korupcijai ir pasākumu komplekss, kurā ietilpst arī korupcijas novēršana, t. i., tādas situācijas nostabilizēšanās, ka korupcija nenotiek, nerodas un neizraisās [12].

Korupcijas iegrožošanā nedrīkst pietiekami nenovērtēt šādus nozīmīgus mehānismus:

- varas sadali [25];

- monopolu ierobežošanu [7, 75];

- vārda brīvību $[24,2]$ u. tml.

Korupcijas novēršana visās trijās dimensijās - iekšējā novēršanā (paša vadības aparāta pūles), ārējā novēršanā (neatkarīgā tiesu sistēma un plašsaziṇas līdzekḷi $[18,105]$, vēlēšanu sistēma [26, 73] u. tml.), kā arī kolektīvā novēršanā (atklātība valsts un pašvaldību iestādēs [19, 18], t. sk. sabiedrības nodrošināšana ar informāciju) - veido spēcīgu, patstāvīgu korupcijas pretdarbības virzienu un var sniegt būtisku ieguldỉjumu korupcijas līmeña mazināšanā ${ }^{1}[23]$.

\footnotetext{
${ }^{1}$ Sistēmiskās pretdarbības korupcijai organizēšana paredz ne tikai korupcijā iesaistīto personu nepastarpinātu vajāšanu, bet arī korupcijas novēršanas un kontroles pasākumus, ar šo jomu saistīto normatīvo aktu pārskatīšanu, amatalgu palielināšanu amatpersonām, likuma prioritāšu noteikšanu un "amatpersonu tīro roku" idejas propagandu.
} 
N̦emot vērā šeit minēto, redzams, ka jebkurā valstī pret korupciju vērstā darbība fokusējas galvenokārt uz koruptīvo pārkāpumu novēršanu [20] un uz koruptīvo pārkāpumu atklāšanu $[4,256]$.

Pieṇēmums, ka valstīs, kurās pieaug sodīto amatpersonu skaits, korupcija samazinās, jo tā tiek efektīivi apkarota, ir log̣isks, tomēr tikpat logisks ir cits pienēemums valstīs, kurās ir efektīva korupcijas novēršanas sistēma, par korupciju sodīto amatpersonu skaits mazinās.

Neapšaubāmi, ka preventīvais darbs ir grūti pierādāms un dokumentējams [14, 98] (piemēram, preventīva rakstura lekcijas amatpersonām var novērst dažus koruptīvus noziedzīgus nodarījumus, bet šo iespējami novērsto noziegumu skaitu nevar nedz skaidri noteikt, nedz arī aprēḳināt). Arī sabiedrības informēšanas un sociālās reklāmas ietekmi ir grūti izmērìt. Turpretī represīvajā segmentā valstij ir daudz vieglāk rast sava darba produktivitātes pierādījumus (piemēram, Korupcijas novēršanas un apkarošanas birojs, gatavojot ikgadējos ziṇojumus par savu darbību, fokusē sabiedrības uzmanību galvenokārt uz sākto kriminālprocesu un sodìto amatpersonu skaitu).

Cīṇas pret korupciju rezultātus uzskatāmāk var parādìt ar korupcijas apkarošanas datiem - statistisko pārskatu, tiesu prakšu zin̄ām u. tml. İpaši populāra šāda pieeja ir Latvijas kaimin̦valstīs - Baltkrievijā un Krievijā. Plašsaziṇas lïdzekḷu sniegtā informācija liecina, ka Baltkrievijā 2015. gadā par koruptīvo noziedzīgo nodarījumu izdarīšanu tika sodītas 485 personas, kas ir par 63\% vairāk nekā 2014. gadā² [8]. Savukārt Krievijā 2014. gada deviños mēnešos tika notiesātas 9196 personas, bet 2015. gada šajā pašã laika posmā - $10064^{3}$ [3].

Analizējot šo informāciju par notiesāto amatpersonu skaita dinamiku, nevar neapstrīdami secināt, vai šajās valstīs korupcijas apkarošana ir kḷuvusi efektīvāka nekā agrāk vai tendence ir pilnīgi pretēja - koruptīvo noziedzīgu nodarījumu skaits ir palielinājies, saglabājoties diezgan stabilam par korupciju sodīto procentam. Atbilde uz šo jautājumu būtu iespējama tikai tad, ja statistikas datus par sodìto amatpersonu skaitu papildinātu ar patiesu informāciju par izdarìto koruptīvo noziedzīgo nodarïjumu skaitu šajos periodos.

Otrkārt, jāatzīmē, ka, iegūstot informāciju par izdarīto koruptīvo noziedzīgo nodarījumu skaitu valstī (informāciju par korupcijas līmeni valstī), ārkārtīgi svarīga

${ }^{2}$ Baltkrievijā apkopoti tieslietu sistēmas darbības 2015. gadā rezultāti. Par izdarītajiem kriminālnoziegumiem notiesāti vairāk nekā 43 tūkst. cilvēku. 2015. gadā par korupciju tika sodīti 485 cilvēki. To ir par 63\% vairāk nekā 2014. gadā. Lielākajai daḷai par korupciju notiesāto piespriesta brīvības atṇemšana uz dažādu laiku. Šajā jomā visizplatītākais noziegums ir zādzība, l̦aunprātīgi izmantojot dienesta stāvokli (204 notiesātie), tai seko kukuḷnemšana (112), kukuḷdošana (75), varas ḷaunprātīga izmantošana (75) un pilnvaru pārsniegšana (27).

${ }^{3}$ Jurijs Čaika paziṇoja, ka 2015. gadā tiesībsargājošās institūcijas cīnai pret korupciju sākušas īstenot kvalitatīvi jaunas pieejas, kas devušas pozitīvus rezultātus. 2015. gada 11 mēnešos atklāts 31 tūkst. korupcijas noziegumu, turklāt palielinās sabiedriski īpaši bīstamo [noziegumu] apjoms, kas būtībā veido korupcijas noziegumu kodolu, t. sk. - kukuḷošanas. Fiksēts ievērojams organizēto, liela apjoma korupcijas noziegumu pieaugums. Vienlaikus palielinājies arī tiesai nosūtìto krimināllietu par šā veida noziegumiem skaits, kā arī personu skaits, kas notiesātas par korupciju. 2015. gada deviṇos mēnešos tiesas pasludinājušas 8582 notiesājošus spriedumus 9196 personām. 
ir izpētes metodolog̣ija. Informācijas ieguvē nedrīkst aprobežoties tikai un vienīgi ar tiesu statistikas datu analīzi, jo tiesu statistika liecina vienīgi par atklātajiem noziedzīgiem nodarījumiem, turklāt tikai par tiem, kuri ir pierādīti un jau stājies spēkā notiesājošs spriedums. Korupcijas līmeṇa noteikšana, pamatojoties tikai un vienīgi uz tiesu statistiku, būtu aplama jau tādēl vien, ka korupcija ir latenta parādība.

Arī pret korupciju vērsto darbību efektivitātes mērījumos statistikas kvantitatīvajiem datiem ir tikai sekundāra nozìme.

Gan korupcijas apkarošanā, gan arī novēršanā statistikas dati l̦auj izmērīt tikai sistēmas produktivitāti, nevis efektivitāti, jo efektivitātes noteikšanā, atškirīibā no produktivitātes, jānemem vērā ne tikai kvantitatīvos, bet arī kvalitatīvos rādìtājus. Efektivitāte galvenokārt tiek raksturota ar jēdzieniem "resursi" un "rezultāti". Nosakot rezultātus, kas jāsasniedz cīṇā pret korupciju, tie jāizteic nevis ar sodìto amatpersonu skaitu, bet gan ar korupcijas līmeṇa samazināšanu valstī un atbildỉbas par iesaistī̌sanos korupcijā nenovēršamību. Var secināt, ka rādītājs "notiesāto amatpersonu skaits", ko parasti lieto tiesu statistikā, neatspoguḷo ne korupcijas līmeni valstī, ne arī pret korupciju vērstās politikas efektivitāti $[11,4]$.

Lai iegūtu pilnīgāku ainu, papildu tiesu statistikai var izmantot starptautiskos indeksus un pārskatus, to skaitā - korupcijas uztveres indeksu (angḷu val. Corruption Perceptions Index, CPI), Globālo korupcijas barometru (Global Corruption Barometer), kukuḷdevēju indeksu (Bribe Payers Index, BPI), Globālo korupcijas pārskatu (Global Corruption Report), Valsts godaprāta sistēmas novērtējumu (National Integrity System Assessments) un Globālo godaprāta ziṇojumu (Global Integrity Report), tomēr nekritiska paḷaušanās uz tajos minētajiem datiem arī nav vēlama. Plaši pazīstamais korupcijas uztveres indekss (CPI), piemēram, tiek kritizēts kopš tā izveides briža [5; 22, 91], norādot uz šādām nepilnībām:

- izmantotās metodikas subjektivitāte (ekspertus un uzṇēmējus lūdz novērtēt vinu valsts pārvaldes aparāta korumpētību);

- aptaujāto respondentu lojalitātes problēma;

- indeksa noteikšanā nav atrisināta problēma ar termina "korupcija" robežu noteikšanu;

- pastāv bažas par pašas Starptautiskās pretkorupcijas organizācijas (Transparency International) ${ }^{4}$ iespējamo korumpētību un politisko ietekmējamību (tiek paustas aizdomas, ka CPI grafiks atspoguḷo nevis reālo iekšējo situāciju valstī, bet gan ārējo novērotāju attieksmi pret valsts valdību).

Tomēr, manuprāt, daudz būtiskāka CPI problēma ir tā, ka - līdzīgi kā mediji -, pārspīlējot korupcijas skandālus, tā var negatīvi ietekmēt sabiedrības uzticēšanos [1,83].

${ }^{4}$ Transparency International ir 1993. gadā dibināta starptautiska nevalstiska organizācija, kas cīnās pret korupciju un pievērš sabiedrības uzmanību šai problēmai. Tā regulāri, reizi gadā, aprēḳina valsts korupcijas uztveres indeksu. 
Šis indekss tiek atspoguḷots plašsaziṇas līdzekḷıs, tāpēc tas var ietekmēt sabiedrības viedokli un ar laiku kḷūt par sabiedrības pašas piepildāmo paregojumu (angḷu val. selffulfilling prophecy) [27, 841]. Turklāt starp korupcijas uztveri un reāliem koruptīviem notikumiem var būt liela atškiriība, ko pastarpināti pierāda arī Latvijas piemērs: atbilstīgi korupcijas uztveres indeksa datiem Latvijas iedzīvotāju uztverē viszemākais korupcijas līmenis bija 2006.-2008. gadā, kad bija pieaudzis viṇu pašu labklājības līmenis. Taču neatbildēts paliek jautājums, vai tiešām korupcijas līmenis 2006.-2008. gadā Latvijā bija mazāks nekā 2005. un 2009. gadā [10, 120]?

Korupcijas līmeņa noteikšanā jāizmanto vairāki un dažādi instrumenti, - arī sociologiskās aptaujas. Latvijā pēdējo piecu gadu laikā ir bijis diezgan daudz pētījumu par korupciju, piemēram, 2011. gadā - "Uzṇēmēju attieksme pret korupcijas jautājumiem", Latvijas uzṇēmēju aptauja (SKDS aptauja 2011. gada novembrī); 2012. gadā - "Attieksme pret korupciju Latvijā", Latvijas iedzīvotāju aptauja (tirgus un sociologisko pētījumu aǵentūras "Latvijas Fakti" aptauja 2012. gada novembrī); 2013. gadā - "Eirobarometra ziṇojums par iedzīvotāju saskarsmi ar korupciju ES dalībvalstīs", "Eirobarometra zin̨ojums par korupciju uzñēmējdarbībā ES dalībvalstīs"; 2014. gadā - "Cik demokrātiska ir Latvija? Demokrātijas audits, 2005-2014" (Latvijas Universitātes Sociālo un politisko pētijumu institūta publikācija, zin. red. Juris Rozenvalds), "Attieksme pret korupciju Latvijā", Latvijas iedzīvotāju aptauja (sabiedriskās domas aptauja "Attieksme pret korupciju Latvijā" 2014. gada aprīili); Eiropas pretkorupcijas ziṇojums (Eiropas Komisija, 2014); 2015. gadā - "Korupcijas novēršana valsts sektorā"5 [9].

Korupcijas līmeṇa noteikšanā mērḳa sociologisiskie pētỉjumi ir daudz lietderīgāki nekā tiesu statistikas dati vai starptautiskie indeksi, jo sociologiskie pētijjumi:

- lauj izzināt korupciju konkrētā jomā - prokuratūrā, policijā, medicīnas iestādēs u. tml.;

- socioloǵisko pētījumu dati tiek iegūti ìsā laika posmā, kas nodrošina datu aktualitāti;

- plašais respondentu skaits, t. sk. intervijas ielās, l̦auj ar lielāku ticamības pakāpi identificēt korupcijas izplatību.

Tomēr arī sociolog̣iskajiem pētījumiem ir trūkumi, piemēram:

- respondentu atbilžu patiesums (atsevišḳas personas var atbildēt uz jautājumiem negodīgi, daži var apzināti sagrozìt savas atbildes);

- nepieciešamība ieguldìt lielus cilvēkresursus pētījuma veikšanai;

- salīdzināmības problēma starp lokālā izpētē iegūtajiem datiem un starptautiskajiem pètijumiem.

Turklāt pētijumos iegūto datu ticamība jāvērtē, atceroties, ka:

- sabiedrība ir heterogēns veidojums, tāpēc dažādas sabiedrības grupas (piemēram, sociālās) atškirīīgi uztver korupciju ${ }^{6}[15,363]$;

\footnotetext{
${ }^{5}$ Prevention of Corruption in the Public Sector in Eastern Europe and Central Asia.

${ }^{6}$ Pēc I. Meni (Y. Meny) domām, tas, vai sabiedrība kādu darbību uzskata par koruptīvu, ir atkarīgs no sabiedrības tolerances līmeña (no skaitliskiem un simboliskiem efektiem), kā arī no kontroles līmeña.
} 
- pirms analizēt iegūtos rezultātus, būtu jānosaka, vai sabiedrība uztver korupciju kā sociālu problēmu un cik liela tolerance pret korupciju ir sociologiskajā pētījumā iesaistītajiem respondentiem;

- sabiedrība atzīst korupcijas sekas par sociālu problēmu tikai tad, kad korupcija sasniedz kritisko robežu ${ }^{7}[17,85]$;

- korupcija tiks sociologiski atpazìta un atzìta par sociālu problēmu tikai tad, kad to vispirms atzīs sabiedrība ${ }^{8}[2,299]$.

Gan tiesu statistikai, gan starptautiskajiem indeksiem, gan arī sociologiskajiem pētỉjumiem ir vairāki trūkumi, tādēl ticama korupcijas līmeṇa noteikšanai būtu lietderīgi visu šo avotu izmantošana vienlaikus.

Treškārt, svarīgi, lai valstu valdību pastiprināta uzmanība korupcijas rādītājiem statistiskajās atskaitēs nefokusētos uz sodīšanas par maznozīmīgiem korupcijas gadījumiem (t. s. apakšējo korupciju) kvantitatīvajiem rādītājiem, atstājot bez ievērības daudz svarīgāku, t. i., augstākā līmeṇa un vērienīgāku korupciju. Augstākā (elitārā) korupcija, atšķirībā no apakšējās korupcijas, parasti ir politiskā, nevis birokrātiskā korupcija un var ietekmēt ievērojami plašāku subjektu loku, turklāt tās sekas var izpausties ne tikai īstermiṇā, bet arī ilgtermiṇā, šādi veicinot elitārās korupcijas sevišķu bīstamību.

Austrumeiropas valstīs, kur visā reg̣ionā prokurori un tiesneši reti uzdrīkstas izmeklēt vadošu amatpersonu darbības [6,23], īpaši būtiski ir pamanìt un turēt uzmanības lokā elitārās korupcijas riskus. Valstīs, kurās korupcija ir plaši izplatīta, panākt notiesāto personu skaita pieaugumu ir daudz vieglāk nekā valstīs, kurās korupcijas līmenis ir zems. Tomēr, kā tika norādìts iepriekš, pret korupciju vērsto politiku jebkurā valstī vajadzētu virzìt tā, lai nepārprotama un neapstrīdama kḷūtu atbildības nenovēršamība visos korupcijas slān,os, it îpaši augstākajā, ko ir daudz grūtāk sodìt nekā sīkus kukuḷnēmējus. Ārkārtīgi svarīgi ir izskaust praksi, ka augstāks korupcijā iesaistītā amats nodrošina viṇam lielāku nesodāmības iespēju [13, 23].

\section{Secinājumi}

1. Raksta mērḳis bija analizēt, vai par koruptīvajiem noziedzīgiem nodarījumiem notiesāto amatpersonu skaits liecina par efektīvu cīnu pret korupciju. Pētījuma rezultāti liecina, ka nepastāv zinātniski pierādìta korelācija starp rādìtāju "par korupciju notiesāto amatpersonu skaits" un valstī realizēto pret korupciju vērsto darbību efektivitāti.

\footnotetext{
7 Pirms traktēt korupciju kā sociālo problēmu, nepieciešams ir sertificēt un klasificēt atsevišķas prasības, piemēram, prasību formulēt korupcijas problēmu, prasību sabiedrībai atzìt šo problēmu kā būtisku, prasību sagaidīt valsts politiskās elites reakciju.

${ }^{8}$ Šis secinājums izriet no pieṇēmuma, ka korupcijas problēma ir saistīta ar realitātes uztveri un interpretāciju. Šādu pieeju apstiprina arī H. Blumers (H. Blumer.), kurš norāda, ka sociālās problēmas ir kolektīvas apziṇas produkts, nevis objektīvu sociālo apstākḷu kopums.
} 
2. Pētot korupcijas novēršanas un apkarošanas jomu, kvantitatīvajiem rādītājiem jāveltī īpaša uzmanība. Rādītājs "par korupciju notiesāto amatpersonu skaits" neliecina par korupcijas līmeni valstī, kā arī par politikas, kas vērsta pret korupciju, efektivitāti.

3. Sodìto personu skaita samazinājums liecina par cīnas pret korupciju samazināšanos tikai tajā gadījumā, ja korupcijas reālais līmenis valstī paliek nemainīgs vai pieaug. Taču gadījumā, ja efektīvas korupcijas novēršanas rezultātā valstī korupcijas līmenis samazinās, tad sodīto personu skaita samazinājumu var vērtēt kā likumsakarīgu.

4. Tiesu statistikas datu dinamikas analīze ir obligāti jāpapildina ar korupcijas lìmeña dinamikas analīzi, n,emot vērā gan starptautiskos indeksus, gan arī sociolog̣isko aptauju rezultātus. Korupcijas pretdarbības duālais raksturs nẹ̣auj precizi noškirt un izmērìt procentos apkarošanas devumu un korupcijas novēršanas devumu. Šo problēmu var novērst, izmantojot sociologiskās aptaujas, kurās uzzinātais sabiedrības viedoklis ir attiecināms uz kopējo vērtējumu par darbībām, kas vērstas pret korupciju.

5. Pret korupciju vērstās politikas efektivitātes galvenais rādītājs ir nevis sodīto amatpersonu skaita pieaugums, bet gan korupcijas līmeņa mazināšanās valstī un atbildības nenovēršamības principa stingra ievērošana. Katrai valstij jāpanāk, lai pie atbildības tiktu saukts nevis lielākais korupcijā iesaistīto personu skaits, bet gan procentuāli lielākais korupcijā iesaistìtais personu daudzums, turklāt vairāk fokusējoties uz augstāka ranga korupcijas gadījumiem, nevis sadzīves korupcijas gadījumiem. Minēto procentuālo lielumu var ietekmēt, gan veicinot korupcijas apkarošanu (sodot lielāko personu skaitu), gan arī mazinot to personu skaitu, kuras izdara koruptīvus noziedzigus nodarijumus (t. i., veicinot korupcijas novēršanu).

\section{Dynamics of Condemned Officials in Context of Fight against Corruption}

\section{Abstract}

The article is devoted to the research of a significant problem - correlation between indicators of the number of condemned officials and efficiency of fight against corruption. In the article it is investigated whether increase/reduction of the number of condemned officials demonstrates a more effective fight against corruption. The results of the research demonstrate that there is no scientifically proven correlation between the indicator of the number of condemned officials and the efficiency of fight against corruption in the state.

Keywords: fight against corruption, dynamics of condemned officials. 
Anatolijs Kriviņš. Notiesāto amatpersonu skaita dinamika pretkorupcijas kontekstā

\section{Literatūra}

1. Behn, R. D. Rethinking Democratic Accountability. Washington, D. C.: Brookings Institution, 2001.

2. Blumer, H. Social Problems as Collective Behavior. Social Problems. 1971, 18 (winter).

3. Chaika, Iu. O. O rezultatakh borbi s korupciei i ee dinamika. (Чайка, Ю. О результатах борьбы с коррупцией и ее Аинамике. 12.01.2016.) Iegūts no: http://prisonlife.ru [sk. 28.03.2016.].

4. Criminal Investigation: An Introduction to Principles and Practice. Peter Stelfox, 2009.

5. Galtung, F. Measuring the Immeasurable: Boundaries and Functions of (Macro). 2006.

6. Kārkliṇa, R. Korupcija postkomunisma valstīs. Rìga: Valters un Rapa, 2005.

7. Klitgaard, R. Controlling corruption. Berkeley: University of California Press, 1988.

8. Korupciia: za god kolichestvo osuzhdennikh uvelichilos na 63\%. (Коррупция: за год количество осужденных увеличимось на 63\%.) Iegūts no: http://mahiliow.regiony.by/\#!news/9328 [sk. 28.03.2016.].

9. Korupcijas novēršanas un apkarošanas birojs. Pētījumi. Iegūts no: http://www.knab.gov.lv/lv/ education/research/index.php [sk. 28.03.2016.].

10. Krivin̦š, A. Korupcijas stāvoklis mūsdienu Latvijā publisko iepirkumu jomā. Starptautiskais zinātnisko darbu krājums. 8. sēj., II daḷa. Rīga: Baltijas Psihologijas un menedžmenta augstskola, 2012.

11. Langseth, P., et al. Emprowering the Victims of Corruption through Social Control Mechanisms (paper presented at IACC meeting). Prague, 2001, Oct. 9, 3-4.

12. Latviešu valodas vārdnīca. Rīga: Avots, 2006.

13. Maidanik, K. Corruption, Criminalization, Kleptocracy: “Transition Phase”? Dead-End Branch? Foundational Structures? Russian Politics and Law 36, 1998, 1.

14. Matisāns, J. Valsts policijas darba efektivitātes vērtēšanas struktūra. Valsts policijas darba efektivitātes vērtēšanas kritēriji: Valsts policijas pasūtītā pētnieciskā projekta pirmā posma materiāli. Rīga: Latvijas Policijas akadēmija, 2008.

15. Meny, Y. Corruption "fin de si и cle": Changement, crise et transformation des valeurs. Revue Internationale Des Sciences Sociales. 1996, 149 (September).

16. Nomokonov, V. On Strategies for combating corruption in Russia. Demokratizacija, 2000; 8 (1).

17. Novikova, O. S. Osobennosti pozicionirovaniia politicheskoi eliti v usloviiakh formirovaniia antikorupcionnoi politiki v Rosiiskoi Federacii. Filosofiia Prava. 2007, 4. (Новикова, О. С. Особенности позиционирования политической элиты в условиях формирования антикоррупционной политики в Российской Федерации. Философия права. 2007, 4.)

18. Patejeva, G. Kh. Rol SMI v formirovanii obshestvennogo mneniia po probleme korupcii pri naznachenii nakazaniia. Pravo. Zakonodatelstvo. Lichnost. 2009, 3 (7). (Патеева, Г. Х. Роль СМИ в формировании общественного мнения по проблеме коррупции при назначении наказания. Право. Законодательство. Аичность. 2009; 3 (7).)

19. Poljakova, T. A. Informacionnaia otkritost kak odin iz faktorov v borbe s korupciei pri postroenii informacionnogo obshestva. Iuridicheskii Mir. 2008, 1 (133). (Поцякова, Т. А. Информационная открытость как оАин из факторов в борьбе с коррупцией при построении информационного общества. Юридический мир. 2008, 1 (133).)

20. Prevention First: National Operating Strategy 2011-2015. Date Published: March 2012. (Prevention First is the operating strategy for New Zealand police). Iegūts no: http://www. police.govt.nz/about-us/publication/prevention-first-national-operating-strategy-2011-2015 [sk. 28.03.2016.]. 
21. Providus: Cīna ar amatpersonu korupciju apstājusies. 09.12.2015. Iegūts no: http://providus.lv/ article/valta-dati-tresdienai [sk. 28.03.2016.].

22. Sik, E., The Bad, the worse and the worst: Guesstimating the level of corruption. Political corruption in transition: A Skeptic's Handbook, Stephen Kotkin and Andras Sajo, Eds. Budapest, 2002. OECD. "The Uses and Abuses of Governance Indicators”. Iegūts no: http://www.oecd. org/document/25/0,2340,en_2649_33935_37081881_1_1_1_1,00.html [sk. 28.03.2016.].

23. Sirotin, A. Opit borbi s korupciei v Singapure. (Сиротин, А. Опыт борьбы с коррупцией в Сингапуре.) Iegūts no: http://www.sudanet.ru/borba_s_corrupciei_v_singapure) [sk. 28.03.2016.].

24. Stapenhurst, R. The Media's Role in Curbing Corruption. Washington, D. C.: World Bank Institute, 2000.

25. The Federalist No. 37. Concerning the difficulties of the Convention in devising a proper form of government. Daily Advertiser. January 11, 1788 [James Madison]. Iegūts no: http://www. constitution.org/fed/federa37.htm [sk. 28.03.2016.].

26. Veshniakov, A. A. Svobodnie i demokraticheskie vibori kak pregrada politicheskoi korupcii. Organizovannaia prestupnost, terorizm i korrupciia. Kriminologicheskii Ezhekvartalnii Almanakh. 2003, 1. (Вешняков, А. А. Свободные и демократические выборы как преграда политической коррупции. Организованная преступность, терроризм и коррупция. Криминологический ежеквартальный альманах. 2003, 1.)

27. Warren, D. E., Laufer, W. S. Are corruption indices a Self-fulfilling prophecy? A Social labeling perspective of corruption. Journal of Business Ethics. 2009, 88. 